\title{
PERAN IBRĀHĪM AL-KŪRĀNĪ DALAM PENGEMBANGAN ISLAM DI NUSANTARA
}

\author{
Frenky Mubarok \\ STAIS Pangeran Dharma Kusuma Indramayu (fbarok@gmail.com)
}

\begin{abstract}
The development of Islam in the Indonesian archipelago (Nusantara) can not be separated from the scholars who have studied at the center of Islamic civilization in the Middle East, especially in the two holy cities of Makka and Medina. This article discusses one of the scholars who became the scholarly reference of students from the archipelago while studying at Haramayn, namely Ibrāhìm Al-Kürānī. Although Ibrāhìm Al-Kürānī never directly preached in the archipelago, but his disciples who came from the archipelago teach his teachings by sourced from the books of his work. The teachings of Ibrāhīm Al-Kūrānī which emphasize the importance of the understanding of Ilmu Hakikat, Ilmu Tariqat, and Ilmu Syari'at are still firmly held by the majority of Muslims today.
\end{abstract}

Keywords: Ibrāhīm Al-Kürānī, Islam, Nusantara

\begin{abstract}
Abstrak
Perkembangan Islam di Nusantara tidak dapat dilepaskan dari ulama-ulama yang telah belajar di pusat peradaban Islam di Timur Tengah, khususnya di dua kota suci Makkah dan Madinah. Artikel ini membahas salah satu tokoh ulama yang menjadi rujukan keilmuan para mahasiswa dari Nusantara ketika belajar di Haramayn, yaitu Ibrāhīm Al-Kūrānī. Meskipun Ibrāhīm Al-Kūrān̄̄ tidak pernah secara langsung berdakwah di Nusantara, namun para muridnya yang berasal dari Nusantara mengajarkan ajarannya dengan bersumber dari kitab-kitab karyanya. Ajaran Ibrāhīm Al-Kūrānī yang menekankan pentingnya pemahaman Ilmu Hakikat, Ilmu Tariqat, dan Ilmu Syari'at tetap dipegang teguh oleh mayoritas umat Islam saat ini.
\end{abstract}

Kata Kunci: Ibrāhīm Al-Kūrān̄i, Islam, Nusantara

\section{A. Pendahuluan}

Di antara seluruh jama'ah haji, orang-orang dari Nusantara merupakan yang paling banyak melakukan Ibadah Haji. Menurut catatan Martin Van Bruinessen sejak pertengahan pertama abad ke-17 raja-raja Jawa mulai mencari legitimasi politik dari para ulama Makkah, meskipun pada saat itu pusat pemerintahan Khilafah Islamiyah terdapat di Turki. Bruinessen juga mencatatat bahwa sekitar tahun 1860-an bahasa Melayu merupakan bahasa kedua di Makkah, setelah bahasa Arab. Hal tersebut membuktikan bahwa tradisi keilmuan yang diterima oleh umat Islam di Nusantara saat ini bersumber langsung dari Haramayn. ${ }^{1}$

${ }^{1}$ Martin Van Bruinessen, "Mencari Ilmu dan Pahala di Tanah Suci Orang Nusantara Naik Haji" dalam Ulumul Qur'an Jurnal Ilmu dan Kebudayaan No. 5 (Jakarta: Lembaga Studi Agama dan Filsafat, 1989), 42. 
Salah satu ulama Haramayn yang menjadi rujukan utama para mahasiswa asal Nusantara adalah Ibrāhīm Al-Kūrānī. Pada artikel ini akan dibahas peran dan pemikiran Ibrāhīm Al-Kūrānī terutama dalam pengembangan pemikiran Islam di Nusantara.

\section{B. Biografi Ibrāhīm al-Kūrānī}

Ibrāhīm ibn Hasan al-Kūrānī al-Shahrazūrī al-Shahrān̄̄ al-Kurd̄̄ al-Madan̄ al-Shafi' '̄e selanjutnya disebut Ibrāhīm al-Kūrān̄i, lahir pada tahun 1025/1616 dan wafat pada tahun 1101/1690. ${ }^{2} \quad$ Berdasarkan namanya tersebut maka Ibrāhīm alKūrān̄ merupakan seorang ulama Madinah yang bermazhab Shāfi'î yang lahir di Sharazur - Kurdi. ${ }^{3}$ Para penulis biografi Arab menyebut Ibrāhīm al-Kūrānī dengan sejumlah laqab seperti Abū al-'Irfān, Burhān al-Dīn, Abū Isḥāq, Abū Muḥammad, dan Abū al-Waqt. ${ }^{4}$ Penyebutan Ibrāhīm al-Kūrānī dengan laqab tersebut juga dapat dijumpai dalam

${ }^{2}$ Oman Fathurahman, Ithā̄f al-Dhakī Tafsir Wahdatul Wujud bagi Muslim Nusantara (Jakarta: Penerbit Mizan, 2012),1.

3 Azyumardi Azra, Jaringan Ulama Timur Tengah dan Kepulauan Nusantara Abad XVII dan XVIII Akar Pembaruan Islam Indonesia (Jakarta: Kencana Prenadamedia Group, 2013), 91

${ }^{4}$ Oman Fathurahman, op.cit., 6. sejumlah salinan naskah karangan Ibrāhīm al-Kurānī. ${ }^{5}$

Ibrāhīm al-Kūrānī mejalani pendidikan dasarnya, yang mencakup pengetahuan Bahasa Arab, kalam, mantiq, filsafat dan lain-lain di kota kelahirannya, Shahrazūr. ${ }^{6}$ Ia kemudian melanjutkan belajar ke kota Baghdad, yang merupakan pusat berkumpulnya ulama asal Kurdi pada periode Kekhalifahan Uthmaniya di abad ke-17. Ibrāhīm al-Kūrān̄̄ menetap di kota Baghdad selama dua tahun, kemudian pindah ke kota Damaskus dan menghabiskan waktu selama empat tahun di kota itu, hingga melanjutkan ke kota Kairo pada tahun 1061/1650. Adapun guruguru Ibrāhīm al-Kūrān̄̄ selama periode pendidikannya tersebut antara lain, Muhammad Sharīf alKūrān̄̄ di Baghdad, 'Abd al-Baqī Taqū al-Dīn al-Hanbalī (w.1070 / 1660) dan Najm al-Dīn al-Ghazzī di Damaskus, dan Abī al-'Azā'im Sulțan ibn Aḥmad al-Mazāḥ̄ Kairo. 'Abd al-Baqī, adalah mufti 16 kota Damaskus dan salah seorang ulama mazhab Hanbalī terkemuka pada pertengahan abad ke-17 M. Di kota Damaskus inilah Ibrāhīm alKūrān̄i secara khusus mempelajari teks-teks fiqih mazhab Ḥanbalī,

\section{${ }^{5}$ Ibid., 7}

${ }^{6}$ Ibid., 7 
selain juga teks-teks karya Taqī alDīn Abū al-'Abbās Aḥmad ibn 'Abd al-Salām ibn 'Abd Allāh ibn Muhammad Ibn Taymīya (661$728 / 1263$ - 1328) dan salah seorang muridnya, Ibn al-Qayyim (1292 1350). Ibrāhīm al-Kūrānī nampaknya cukup akrab dengan pemikiran Ibn Taymīya, walaupun ia secara khusus tidak menjadikan kitab-kitab karya Ibn Taymīya dalam Ithaf al-Dhākī namun dalam pembahasan tertentu ia menjadi pengkritik sekaligus pembela pemikiran-pemikiran Ibn Taymīya. Misalnya ketika Ibrāhīm al-Kūrānī menjelaskan pernyataan yang dilontarkan oleh Ibn Taymīya yang ia kutip dari kitab al-Ițqān karya al-Suyūṭi: ${ }^{7}$

Dalam statemennya, Ibn Taymīya menjelaskan bahwa banyak para penafsir al-Quran - terutama di kalangan Sufi - yang menafsirkan alQuran yang secara maknawi adalah benar - dalam arti tidak bertentangan dengan dasar-dasar agama - akan tetapi makna tersebut tidak ditunjukan secara tekstual oleh alQuran. Karena itu menurut Ibn Taymīya penafsiran tersebut adalah salah di dalam pengambilan dalil bukan pada hasil dari penafsirannya (madlūl).

${ }^{7}$ Ibrāhīm al-Kūrānī, "Ithāē al-Dhakī”, dalam Oman Fathurahman, op.cit., 190.
Menyikapi pernyataan Ibn Taymīya di atas, Ibrāhīm al-Kūrānī membenarkan bahwasanya penafsiran yang dilakukan oleh para Sufi adakalanya keluar dari makna tekstual dari ayat-ayat al-Quran. Menurut Ibrāhīm al-Kūrānī jika Ibn Taymīya mengatakan bahwa berdasarkan hal tersebut para Sufi telah menyimpang dari kebenaran maka hal tersebut adalah keliru, tetapi jika Ibn Taymīya hanya meyakini bahwa penafsiran para Sufi terkadang tidak sesuai dengan makna lahir dari teks maka hal tersebut dapat diterima, dikarenakan dalam sebuah teks terdapat makna lahir maupun makna batin. ${ }^{8}$

Ibrāhim al-Kūrānī tampaknya memiliki keleluasaan dalam mepelajari berbagai literatur Islam dalam berbagai bahasa, karena selain bahasa Arab, ia juga fasih berbahasa Persia dan Turki. ${ }^{9}$ Ketika di Kairo, selain belajar kepada Abī al-'Azā'im Sulțan ibn Aḥmad al-Mazāhī, Ibrāhīm al-Kūrānī juga belajar kepada Muḥammad ibn 'Alā al-Dīn al-Bābilī, sebelum ahirnya belajar kepada sejumlah ulama di Madinah seperti Abū al-Mawāhib Aḥmad ibn 'Alī al-Shanāwī, Muhammad Sharīf ibn Yūsuf al-Kūrān̄̄, 'Abd al-Karīm ibn Abī Bakr al-Ḥusaynī al-Kūrān̄̄

\footnotetext{
${ }^{8}$ Ibid., 190

${ }^{9}$ Oman Fathurahman, op.cit., 7-8.
} 
dan secara khusus kepada Aḥmad alQushāshī (w. 1660). ${ }^{10}$

Pertemuan Ibrāhīm al-Kūrānī dengan Aḥmad al-Qushāshī, terjadi ketia ia sedang menunaikan ibadah haji di kota Makkah. Aḥmad alQushāshī merupakan gurunya yang paling berpengaruh, hingga dapat membujuk dirinya untuk menetap di Haramayn. Hubungan Ibrāhīm alKūrānī dengan gurunya tersebut semakin dekat ketika ia menikahi putri gurunya tersebut. Walaupun alQushāshī merupakan guru utama Ibrāhīm al-Kūrānī, tetapi tidak menghalanginya untuk belajar kepada ulama-ulama lain yang ada di Madinah seperti Muhammad alBābilī dan 'Īsā al-Tha'ālibī. ${ }^{11}$

Aḥmad al-Qushāshī sendiri merupakan murid dari Sayyid Sibgat Allāh bin Rūḥ Allāh Jamāl alBarwajī (w. 1015/1606) dan Ahmad al-Shināwī (1. 975/1567). Setelah Aḥmad al-Shināwī wafat, ia kemudian memegang tanggung jawab atas penyebaran Tariqah Shațariya khusunya di Haramayn. Salah satu perubahan yang paling menonjol dari kemurshidan Aḥmad al-Qushāshī adalah upayanya dalam

\footnotetext{
${ }^{10}$ Ibid., 8
}

${ }^{11}$ Basheer M. Nafi, Tașawwuf and Reform in Pre-Modern Islamic Culture: In Search of Ibrāhīm al-Kūrānī, dalam Die Welt des Islams, (Brill: Vol. 42. Issue 3, 2002), 321. mereorientasi ajaran Tariqah Shațtariya yang awalnya cenderung lebih mengedepankan aspek mistis yang bersifat ritual menjadi sebuah tarekat yang mengajarkan perpaduan antara aspek mistis dengan aspek Syari'at, atau yang kemudian disebut oleh Fazlur Rahman dan Azyumardi Azra dengan istilah 'neo-sufisme'. ${ }^{12}$

Tidak berbeda dengan gurunya, Aḥmad al-Qushāshī, Ibrāhīm al-Kūrān̄̄ juga dikenal sebagai seorang ulama Haramayn yang sangat menekankan makna penting Syari'at di samping tasawuf. Sehinga seorang sufi, menurut Ibrāhīm al-Kūrānī, tidak sepatunya membiarkan praktik mistisnya bertentangan dengan Syari'at dan kewajiban agama lainnya. ${ }^{13}$ Karenanya, ia berupaya untuk mengambil benang merah dari khazanah keilmuan yang ia warisi baik dari segi fiqih, teologi, tasawuf hingga filsafat. Sikap Ibrāhīm alKūrān̄̄ seperti yang diakuinya sendiri dalam kitab Ithaf al-Dhākī, terinsipirasi dari perkataan Umar bin al-Khațāb:

12 Oman Fathurahman, "Tarekat Syattāriyah Memperkuat Ajaran Neosufisme", dalam Mengenal dan Memahami Tarekat-Tarekat Muktabarah di Indonesia (Jakarta: Kencana, 2011), 160.

13 Oman Fathurahman, Itḥāf al-Dhakī Tafsir Wahdatul Wujud bagi Muslim Nusantara (Jakarta: Penerbit Mizan, 2012), 118 
Dan pahamilah sikap saudaramu dalam sisi terbaiknya, hingga ia menunjukan kepadamu pandangan yang lebih baik bagimu, dan janganlah kamu menganggap buruk atau jelek ucapan yang berasal dari seorang Muslim, sejauh kamu dapat menemukan sebuah penafsiran yang baik baginya. ${ }^{14}$

Watak dasar Ibrāhīm al-Kūrānī ini tentu saja tidak terbentuk begitu saja, melainkan sangat dipengaruhi, baik oleh latar belakang pedidikannya maupun konteks sosial intelektual yang terjadi pada masanya. Abad ke 17 dapat dikatakan sebagai abad kebangkitan bagi para intelektual pembaharu. Jalur sutra perdagangan laut yang semakin ramai dengan kapal-kapal yang berlayar dari Eropa hingga Asia Timur berpengaruh juga pada arus jama'ah ibadah haji dari seluruh penjuru dunia termasuk kepulauan Nusantara. Pertemuan antar sesama muslim dari penjuru dunia ternyata tidak hanya sekedar melakukan ibadah haji, akan tetapi mereka pun juga melakukan perjalanan menuntut ilmu (rihlah 'ilmiyah) dari beberapa tokoh agama yang ditemuinya di Haramayn. Hal ini menjadikan kota Makkah dan Madinah berkembang menjadi pusat keilmuan yang bersifat heterogen. Karenanya tidak mengherankan jika terjadi

\footnotetext{
${ }^{14}$ Ibrāhīm al-Kūrānī, op.cit., 238.
}

persinggungan antara berbagai aliran baik dari disiplin ilmu fiqih maupun tasawuf yang sering kali memunculkan suatu corak pemikiran tertentu yang merupakan perpaduan dari beberapa aliran fiqih atau tasawuf.

\section{Kedudukan Ibrāhīm al-Kūrānī dalam Jejaring Ulama Nusantara}

Awal penelitian tentang jejaring ulama Nusantara dengan ulama di Timur Tengah dilakukan oleh Snouck Hurgronje dalam bukunya Mecca (1889), yang merupakan hasil studi lapangan langusung di kota suci Makkah. Penelitian selanjutnya dilakukan oleh murid Hurgonje yaitu D.A. Rinkes yang menulis tentang 'Abd al-Ra'uf al-Singkili untuk desertasi Ph.D-nya (1909). Dua murid Snouck Hurgronje lainnya yaitu BJ.O. Schrieke (1916) dan H. Kraemer (1921) menulis tentang manuskrip Jawa anonim abad 16 yang mengandung ajaran sufisme alGhazali. G.W.J. Drewes, seorang peneliti dari Leiden menulis desertasinya pada tahun 1925 tentang manuskrip abad 19 dari ulama Jawa, terutama tentang tarekat lokal yang disebut Akmaliyah atau Haqmaliyah. J. Doorenbos menulis tentang puisipuisi sufi besar Melayu abad 16, Ḥamzah Fansūrī, pada tahun 1933. C.A.O. van Nieuwenhuijze's menulis 
studi yang mengagumkan tentang sufi Melayu, Shams al-Dīn Pasai, pada tahun $1945 .^{15}$

Penelitian yang lebih komprehensif tentang jejaring ulama Nusantra kemudian dilakukan oleh Azyumardi Azra. Menurut Azyumardi Azra ciri paling menonjol dari jaringan ulama abad $17 \mathrm{M}$, adalah bahwa saling pendekatan (reapprochment) antara para ulama yang berorientasi pada Syari'at (fuqaha) dan para sufi mencapai puncaknya. Konflik yang berlangsung lama antara kedua kelompok cendikiawan Muslim ini tampaknya telah banyak berkurang; sikap saling pendekatan atau rekonsiliasi di antara mereka banyak diajarkan oleh para pemuka ulama seperti Abū al-Qāsim al-Qushayrī (376-465/986-1072) dan Abū Ḥāmid al-Ghazālī (450-505/1058-1111) yang sering menjadi rujukan utama dari sufi-sufi Nusantara seperti 'Abd al-Ra'ūf al-Sinkīlī, 'Abd al-Ṣamad al-Falimban̄̄, Muḥammad Nafis alBanjārī, dan lainnya. Karenanya pada abad ini banyak di antara mereka yang ahl al-shari'a (fuqahā) dan ahl al-haqiqah (sufi) sekaligus. ${ }^{16}$

${ }^{15}$ Martin Van Bruinessen, "Studies of Sufism and the Sufi Orders in Indonesia Source", dalam Die Welt des Islams (Brill: Vol. 38, Issue 2, Jul., 1998), 195-196

16 Azyumardi Azra, Jaringan Ulama Timur Tengah dan Kepulauan Nusantara Abad XVII
Azyumardi Azra menyebutkan bahwa, bagi Ibrāhīm al-Kurān̄̄, rekonsiliasi antara Syari'at dan tasawuf tidak boleh dianggap enteng. Dalam membahas masalah ini, argumennya tajam dan filosofis. Hal ini karena Ibrāhīm al-Kūrān̄̄ sangat akrab dengan berbagai jenis wacana intelektual, dari kalam Mu'tazila dan Ash'ariya hingga mististiko-filosofis Ibn 'Arābī dan filsafat peripatetik Ibn Sina. Dalam hal ini, dia merupakan tokoh dengan kedudukan khusus di dalam jaringan ulama. Tetapi harus diingat, nadanya selalu bersifat mendamaikan dan merengkuh semua pihak. Jadi, di samping menekankan kepatuhan penuh pada Syari'at, dia menjadikan seruan pada pengakuan terhadap kashf, sebagai jalan yang benar untuk memahami makna batiniah dari alQuran dan al-Hadits. ${ }^{17}$

Genealogi (sanad) keilmuan Ibrāhīm al-Kūrānī pada ahir abad 18 $M$ ternyata juga sampai kepada Muḥammad bin 'Abd al-Wahhab (1703-92) dan Wali-Allāh Dihlawī (1703-62). Hal ini membuktikan bahwa lingkaran ulama Makkah Madinah menjadi akar yang kuat dari perkembangan intelektual

dan XVIII Akar Pembaruan Islam Indonesia (Jakarta: Kencana Prenadamedia Group, 2013), 125.

${ }^{17}$ Ibid., 139. 
selanjutnya, dan menyiratkan pertanyaan tentang bagaimana kedudukan Ibrāhīm al-Kuran̄̄ pada evolusi intelektual, dari para ulama sufi yang berafiliasi dengan doktrin wahdat al-wujūd menjadi salafi dan anti-sufi seperti Ibn 'Abd al-Wahhab. Basheer M. Nafi menduga dengan kuat bahwa para ulama anti-sufi tersebut hanya menyandarkan genealogi keilmuannya kepada Ibrāhīm al-Kūrānī sebagai ahli alHadits tetapi tidak mengambil keilmuan lainnya terutama tasawuf. ${ }^{18}$

A.H. Johns, sebagaimana dikutip oleh Basheer M. Nafi, menemukan bahwa ketokohan Ibrāhīm al-Kūrānī di Madinah sangat dekat dengan kebangkitan Islam di Asia Tenggara pada abad ke tujuh belas, terutama dengan ulama Aceh, 'Abd al-Ra'ūf (w. 1690). Masih menurut Johns, Ibrāhīm al-Kurānī juga merupakan tokoh yang tergabung dalam kebangiktan Ulama yang berpusat di Hijajjī, terutama di kota suci Madinah pada abad tujuh belas dan delapan belas, yang memiliki jaringan murid yang tersebar diseluruh penjuruh dunia Muslim, seperti Persia, Aljazair, Jazirah Arab, India, Syiria, Asia Tenggara, dsb. ${ }^{19}$

${ }^{18}$ Basheer M. Nafi, op.cit., 308

${ }^{19}$ Ibid., 307
Ibrāhīm al-Kūrānī merupakan ulama generasi kedua dalam jaringan Neo-Sufism yang berpusat di Haramayn, adapun generasi pertamanya antara lain Ahmmad alQushāshī (991/1583-1071/1661) dan Muḥammad al-Bābilī (1000/15921077/1666). Ulama yang merupakan gerasi kedua selain al-Kūrāni antara lain 'Abdullāh ibn Sālim al-Basrī dan Ḥasan bin 'Alī al-'Ujaymī. Generasi ketiga yaitu, Muhammad ibn Ibrāhīm al-Kūrānī dan Muḥammad Ḥayāt al-Sindī. Ulamaulama tersebut berasal dari mazhab fiqih Sunni yang berbeda, yang juga berafiliasi dengan berbagai tarekat seperti Khalwatiyya, Naqshabandiyya, Shādiliyya, Suhrawardiyya, Shațariyya dan Qādiriyya, begitupun juga ulamaulama tersebut merupakan para ulama al-Hadits yang terkemuka. ${ }^{20}$

Walaupun pusat pengajaran Ibrāhīm al-Kūrān̄i adalah di kota Madinah, akan tetapi di kota Makkah pun terdapat tokoh-tokoh yang merupakan pengikutnya, salah satunya adalah seorang teolog yang berpengaruh asal Kurdi yaitu Muhammad bin 'Abd al-Rasūl alBarzanjī (w. 1103/1691) yang sangat mengutuk para ulama yang berkomentar pahit terhadap doktrin Ibn 'Arābī, terutama kepada ulama 
asal Yaman, Șālih al-Maqbalī (w. 1109/1699) yang dengan tegas menolak doktrin Ibn 'Arābī dalam mazhab dan pemikirannya. ${ }^{21}$

Prinsip dasar pembahasan Ibrāhīm al-Kūrānī dalam karyakaryanya adalah menerima ajaranajaran umum yang dikemukakan oleh para ulama dalam tradisi Sunni dan mereka yang disebut sebagai generasi salaf al-șālih. ${ }^{22}$ Prinsip ini menitik tekankan bahwa dalam disiplin keilmuan Islam dari syari'ah, țariqah dan haqiqah adalah prinsipprinsip yang tidak bertentangan satu sama lain, bahkan setiap muslim harus berusaha untuk memadukan ketiga unsur tersebut dalam kehidupan beragamanya.

Menurut Azyumardi Azra, Ibrāhīm al-Kūrānī adalah ulama yang paling tanggap menjawab pertanyaan-pertanyaan yang diajukan kepadanya baik secara langsung maupun tidak. Setidaknya sembilan dari 49 karyanya yang dicatat di Baghdad dimaksudkannya sebagai tanggapan terhadap berbagai masalah pelik, sejak dari hubungan

21 Alexander Knysh, "Ibrāhīm al-Kūrānī (d. 1101/1690), an Apologist for Wahdat alWujūd", dalam Journal of The Royal Asiatic Society (Cambrige: Cambrige Univesity Press, Vol. 5. No. 1. Apr., 1995), 46.

${ }^{22}$ Oman Fathurahman, Ithāf al-Dhakī Tafsir Wahdatul Wujud bagi Muslim Nusantara (Jakarta: Penerbit Mizan, 2012), 5
Tasawuf dengan Syari'at, dan pertanyaan apakah manusia akan dapat melihat Tuhan, hingga masalah taqlìd (mengikat secara buta). Adapun kitab Ithāa al-Dhāki merupakan karya yang paling penting dari semua karya-karya Ibrāhīm al-Kurānī. ${ }^{23}$ Sikap keilmuannya yang luas dan moderat tersebut didapatkannya dari pengembaraannya dalam menuntut ilmu dari berbagai guru hingga ahirnya menetap di Haramayn yang dalam istilah Azyumardi Azra merupakan panci pelebur (melting pot) yang meleburkan berbagai tradisi kecil Islam sehingga membentuk sintesis baru yang sangat condong kepada tradisi besar. Akan tetapi yang dimaksud dengan "sintesis baru" menurut Azra tidak sepenuhnya merupakan perkembangan baru dalam sejarah tradisi-tradisi sosial dan intelektual Islam. Meski demikian, "sintesis baru" tersebut memiliki beberapa ciri khas jika dibandingkan dengan tradisi sebelumnya; dan dalam banyak hal ia juga mengandung beberapa unsur kesinambungan dengan tradisi-tradisi sebelumnya. Langkah kembali kepada sikap ortodoksi Sunni yang mencapai momentum setelah abad ke 12 tampaknya mencapai kulminasi pada

${ }^{23}$ Azyumardi Azra, op.cit., 139 
abad 17 di mana Ibrāhīm al-Kūrānī hidup. ${ }^{24}$ Adapun melting pot tersebut berisi khazanah pemikiran dari yang berciri al-'ulum al-naqliyy yang bersisi kajian hukum fiqih dan alHadits, al-suluk al-ma'nawi yang berisi praktek-praktek asketis tarekat, dan al-'ulum al-'aqliyya yang berisi filsafat, teologi dan tasawuf teoritis ('irfan).

Silang pendapat antar berbagai disiplin ilmu yang terjadi di Haramayn tersebut mengakibatkan timbulnya "neo-sufisme". Istilah yang diciptakan oleh Fazlur Rahman ini memiliki pengertian bahwa neosufisme adalah tasawuf yang telah diperbaharui, yang terutama dilucuti dari ciri dan kandungan ecstatic, dan digantikan dengan kandungan yang tidak lain dari dalil-dalil ortodoksi Islam. Tasawuf model baru ini menekankan dan memperbaharui faktor-faktor moral asli dan kontrol diri yang puritan dalam tasawuf dengan mengorbankan ciri-ciri berlebihan dari tasawuf populer yang menyimpang (unorthodox sufism), pusat perhatian neo-sufisme adalah rekonstruksi sosiomoral dari masyarakat Muslim. Ini berbeda dengan tasawuf sebelumnya, yang terutama menekankan individu bukan masyarakat. Akibatnya, Fazlur Rahman menyimpulkan, karakter keseluruhan neo-sufisme tak pelak lagi adalah puritan dan aktivis. ${ }^{25}$

\section{Peran Ibrāhīm al-Kūrānī dalam Pendidikan Islam Nusantara}

Meskipun Ibrāhīm al-Kūrān̄̄ tidak pernah secara langsung berdakwah di Nusantara, namun murid-muridnya tersebar di seluruh penjuru Nusantara. 'Abd al-Ra'uf alSingkili adalah salah satu murid Ibrāhīm al-Kūrānī yang memiliki peran penting bagi pengembangan pendidikan di Aceh.

Selain melalui para muridnya, Ibrāhīm al-Kūrānī juga mengarang sebuah kitab yang ditunjukan khusus untuk umat Muslim Nusantara, yang berjudul Ithậf al-Dhākī bi sharh alTuhfa al-Mursala ilà al-Nabì șalla Allāh 'alayh wa-sallam memiliki arti "Persembahan kepada Sang Cerdas: Penjelasan atas Kitab Sebuah Persembahkan kepada Nabi saw." Seperti yang diisyaratkan oleh judulnya, Itḥăf al-Dhākì merupakan sebuah komentar terhadap kitab yang berjudul al-Tuhfa al-Mursala ilà alNabī șalla Allāh 'alayh wa-sallam. Kitab terahir ini ditulis oleh Faḍl Allāh al-Hind̄̄ al-Burhānfūrī (w. 1620) pada tahun 1590. AlBurhānfūrī sendiri merupakan kawan dekat dari Sayyid Sibgat Allāh bin

${ }^{24}$ Ibid., 124

${ }^{25}$ Ibid., 126 
Rūḥ Allāh Jamāl al-Barwajī (w. 1015/1606) yang merupakan kakek guru dari Ibrāhīm al-Kūrānī. ${ }^{26}$ Dengan demikian karya alBurhānfūrī yaitu kitab al-Tuhfa alMursala sudah cukup dikenal di dalam khazanah intelektual tarekat Shaț̣āriyya, maka wajarlah jika Ibrāhīm al-Kūrānī merasa terpanggil untuk membuat sharh terhadap kitab tersebut ketika banyak kalangan tertuama jama'ah al-jawiyyin - yang kesulitan untuk memahami doktrindoktrin sufistik yang ada di dalamnya.

Menurut Oman Fathurahman, walaupun Ithāa al-Dhāki merupakan komentar dari al-Tuhfa al-Mursala, akan tetapi kitab ini juga dapat dianggap sebagai salah satu tafsir terpenting ajaran-ajaran tasawuf filosofisnya Ibn 'Arābī, terutama mengenai konsep wahdat al-wujūd. Istilah wahdat al-wujūd sendiri sebenarnya tidak dipakai oleh Ibrāhīm al-Kūrānī ketika menjelaskan pemikiran Ibn 'Arābī ini, Ibrāhīm al-Kūrāni lebih menyukai istilah tawhid al-wujūd. Sikap al-Kūrānī tersebut adalah wajar dikarenakan Ibn 'Arābī sendiri sebenarnya memang tidak pernah

26 Oman Fathurahman, "Tarekat Syattāriyah Memperkuat Ajaran Neosufisme", dalam Mengenal dan Memahami Tarekat-Tarekat Muktabarah di Indonesia (Jakarta: Kencana, 2011), 158 menggunakan wahdat al-wujūd sebagai sebuah istilah baku untuk pemikiran sufistiknya. Istilah wahdat al-wujūd pada struktur pemikiran metafisika Ibn 'Arābī muncul dari sufi asal Anatolia Șadr al-Dīn alQūnawī (w.673/1274) yang juga merupakan murid sekaligus anak tiri Ibn 'Arābī. Banyak para sarjana yang menegaskan bahwa al-Qūnawī adalah tokoh utama yang menekankan ontologi pemikiran sufistik Ibn 'Arābī tersebut dan memadukannya dengan pemikiran filsafat Ibn Sīnā (w. 428/1037). ${ }^{27}$

Ithāf al-Dhākī memang bukan satu-satunya karya Ibrāhīm al-Kūrān̄̄ yang mengemukakan penjelasan atas pemikiran-pemikiran filosofis Ibn 'Arābī, karena ia juga mengemukakan topik yang sama, dengan pendekatan yang berbeda, dalam karya-karyanya yang lain seperti Mațla' al-jūb bi-tahquīq altanzīh fi waḥdat al-wujūd dan Tanbīh al-'uqūl 'alà tanzīh alșüfiyah 'an i'tiqād al-tajsìm wa-al'aynīyat wa-al-ittihāad wa-al-hulūl. Begitupun Ithāaf al-Dhākī, bukanlah karya terpanjang yang pernah ditulis Ibrāhīm al-Kūrān̄̄, karena karyanya yang lain, yakni Qaṣd al-sabil ilà tawhìd al-Haq al-Wakìl, yang merupakan penjelasan atas kitab alManżūmat karya gurunya, Aḥmad al-

${ }^{27}$ Alexander Knysh, op.cit., 39 
Qushāshī, hampir dua kali lipat lebih panjang dari Ithāa $a l-D h \bar{a} k \bar{l}{ }^{28}$

Oman Fathurahman dalam penelitiannya, menemukan penulisan dua judul berbeda dalam karya Ibrāhīm al-Kūrānī yang dibuat berdasarkan permintaan Jama'ah alJawiyyin ini. Selain ditulis dengan diksi al-Dhākī (dengan huruf dhal / ذ) yang berarti 'cerdas', ternyata pada salinan kitab yang lain judul dari kitab ini ditulis dengan diksi al$Z \bar{a} k \bar{l}$ (dengan huruf zay / j) yang berarti 'suci'. ${ }^{29}$ Sebenarnya jika dilihat dari segi kontekstualnya sebagai kitab yang beirisi ilmu hakikat atau tasawuf baik 'kecerdasan' atau pun 'kesucian' saling berkorelasi satu sama lain. Hal ini karena dalam mempelajari ilmu hakikat, selain kecerdasan, kesucianpun merupakan faktor terpenting guna mendalami ilmu ini. Akan tetapi karena redaksi al-Dhāki lebih banyak dari pada al-Zākī maka Oman Fathurahman lebih memiliki redaksi al-Dhāki sebagai judul karya Ibrāhīm al-Kūrānī ini.

Menurut Alexander Knysh Ithāf al-Dhākī merupakan kitab yang menitik beratkan pembelaan Ibrāhīm al-Kūrānī terhadap doktrin wahdat

${ }^{28}$ Oman Fathurahman, Ithāf al-Dhakī Tafsir Wahdatul Wujud bagi Muslim Nusantara (Jakarta: Penerbit Mizan, 2012), 2

${ }^{29}$ Ibid., 3 al-wujūd Ibn 'Arābī. Para ulama Muslim memang sering kali menjadikan Ibn 'Arābī sebagai titik serang dalam pembahasan teologi dan menganggapnya sebagai bid'ah yang terbesar. Kritikan terhadap Ibn 'Arābī, secara ringkas dapat ditemukan dalam karya-karya Ibn Taymiya (w. 728/1328) yang merupakan ulama besar yang sangat berpengaruh. ${ }^{30}$

Referensi utama yang digunakan oleh Ibrāhīm al-Kūrānī dalam Ithāf al-Dhākī selain alFutūhat al-Makiyya karya Ibn 'Arābī, adalah kitab karya Șadr alDīn Muḥammad ibn Isḥāq alQūnawī (605-673/1207-1274) yang berjudul I'jāz al-Bayān. Uraian alQūnāwī dalam kitabnya tersebut ternyata menjadi refrensi utama Ibrāhīm al-Kūrānī untuk menjelaskan doktrin-doktrin mistikofilosofis Ibn 'Arabī. Selain itu kitab Mashra' al-Khușūṣ ilà ma'āni alNușūṣ karya 'Ālā' al-Dīn 'Alī ibn Aḥmad al-Mahā'imī (776-835/13741432) yang merupakan sharh atas kitab al-Nușūs karya Șadr al-Dīn alQūnawī juga ikut membangun pemikiran Ibrāhīm al-Kūrānī. AlMahā'imī sendiri adalah seorang ulama yang menjadi bagian dari Komunitas Nawait, yaitu komunitas imigran yang berasal dari Arab-

${ }^{30}$ Alexander Knysh, op.cit., 42 
Persia yang menetap di India, ${ }^{31}$ karenanya dapat dikatakan memiliki hubungan yang erat dalam tarekat Shațariyya yang juga berkembang di India. Penafsir pemikiran Ibn 'Arabī yang lain, yaitu Nūr al-Dīn 'Abd alRaḥmān ibn Aḥmad al-Jāmī (817/898-1414/1492) yang merupakan pengarang kitab $A l$ Durrah al-Fākhirah juga dijadikan oleh Ibrāhīm al-Kūrānī guna mensistematisasi pemikiran Ibn 'Arabī.

Ketika membela penafsiran yang dilakukan oleh para sufi atau yang biasa disebut dengan Tafsir Ishārī, al-Kūrānī menjadikan kitab Al-Itqān fì 'Ulūm al-Qur'ān, karya Abū al-Faḍl 'Abd al-Raḥmān ibn Abi Bakr Jalāl al-Dīn al-Khuḍayrī alSuyūṭī (849-911/1445-1505) sebagai referensinya. Dalam al-Itqān, alSuyūṭi menjelaskan bahwa dalam memahami teks al-Quran ataupun alHadits harus dipahami terlebih dahulu bahwa makna dari teks tersebut tidaklah bersifat tunggal, akan tetapi memiliki makna yang beragam tergantung kecenderungan orang yang menafsirkannya. Dengan demikian al-Suyūṭ̂̄ mengingatkan untuk selalau bersikap bijaksana dalam memahami teks yaitu dengan tidak menjustifikasi bahwa hanya pemahaman dirinya saja yang benar,

${ }^{31}$ Oman Fathurahman, op.cit., 252 karena hal tersebut akan menyempitkan posisi al-Quran sebagai teks suci yang pada hakikatnya bersifat universal. Adapun contoh-contoh tafsir Ishārī yang dikutip oleh Ibrāhīm al-Kūrān̄̄ salah satunya bersumber dari kitab Mishkāt al-Anwāar karya Abū Ḥāmid al-Ghazālī (w. 505/1111). Kitab alGhazālī yang lain, yang pastinya selalu dijadikan rujukan bagi para ulama-ulama Sunni yaitu kitab Ihya Ulūm al-Dīn juga merupakan referensi Ibrāhīm al-Kūrānī.

Kitab Al-Kashāf 'an Haqāiq al-Tanzīl wa-'Uyūn al-Aqāwil fi Wujūh al-Ta'wīl, karya Abū alQāsim Mạ̣mūd ibn 'Umar alZamakhsharī merupakan kitab tafsir yang selalu dijadikan rujukan Ibrāhīm al-Kūrānī ketika akan malakukan analisis linguistik kepada teks al-Quran. Adapun kitab-kitab tafsir yang juga merupakan rujukan Ibrāhīm al-Kūrān̄i di antaranya adalah Tafsir al-Haqā'iq karya Abū 'Abd al-Raḥmān al-Sulamī, Tafsir Anwār al-Tanzīl fì Asrār al-Ta'wīl karya 'Abd Allāh ibn 'Umar ibn Muhammad ibn 'Alī al-Shīrāzī alImām Nașīr al-Dīn Abū Sa'īd alQāọī al-Bayḍawī (w. 691/1291).

Terdapat banyak kitab lain yang dijadikan referensi Ibrāhīm alKūrān̄̄ dalam membangun pemikirannya yang di antaranya 
yaitu: Najāt al-Hāàirīn karya Kamāl al-Dīn 'Abd al-Razzāq al-Ka'shān̄̄, Al-Risālah karya Abū al-Qāsim alQushayrī, Al-Ibānah fi Ușūl alDiyānah karya Abū al-Ḥasan 'Alī ibn Ismā'īl al-Ash'arī (260-324/874936), Sharh al-Maqāṣsid karya Sā’d al-Dīn Mas'ūd ibn 'Umar alTaftāzanī (722-793/1322-1390), Ilāhìyāt al-Shifā karya Abū 'Alī alHusayn ibn 'Abd Allah Ibn Sīnā (370-428-980-1037), Hāshiyat Sharh al-Tajrīd karya Jalāl al-Dīn Muhammad al-Dawān̄̄ (830903/1426-1502), Sharh al-Mawāqif karya Al-Amidī, Al-Mughnī al-Labīb karya Ibn Hishām, Tawālī al-Ta'nīs karya Al-Hafĩz Ibn Hajar, Miṣbạh alUns Bayn al-Ma'qūl wa al-Mashhūd fi Sharh Miftāh Ghayb al-Jam' waal-Wujūd karya Shams al-Dīn Muḥammad ibn Ḥamzah al-Fanārī, Mawāqi' al-Nujūm karya Ibn 'Arābī, Arba'inn karya 'Abd al-Qādir alRuhāwī, Fath al-Bārī karya Al-Ḥafīz Ibn Hajar dan Al-'Awārif karya Shihāb al-Dīn al-Suhrāwardi. Dikarenakan hal tersebut maka Ibrāhīm al-Kūrānī merupakan seorang ulama abad 17 yang memiliki wawasan yang cukup luas yang mendasarkan pemikirannya tidak hanya sebatas spekulasi akan tetapi juga bersandar pada ulamaulama sebelumnya.

\section{E. Pandangan tentang Ilmu Hakikat dan Syari'at}

Hakikat berasal dari kata haqīqa dalam Bahasa Arab. Haqīqah sendiri sering dimaknai sebagai sesuatu yang menunjukan kebenaran esoteris. Dalam pengertian ini, Hakikat merupakan unsur ketiga setelah Syari'at yang merupakan kenyataan eksoteris dan Tariqat sebagai tahapan esoterisme. ${ }^{32}$ Hal ini senada dengan pendapat Sayyid Muḥsin al-Mūsawī al-Tabrīzī, yang menyatakan bahwa sesungguhnya Tariqat adalah penyempurna bagi Syari'at, dan Hakikat adalah penyempurna bagi Tariqat. ${ }^{33}$

Menurut 'Ālā' al-Dīn 'Alī ibn Aḥmad al-Mahā'imī (776-835/13741432) seperti yang dikutip oleh Ibrāhīm al-Kūrān̄̄, Ilmu Hakikat adalah ilmu yang membahas perihal Wujūd (ậwāl al-wujūd) dari segi sebagai diri-Nya, dan dari segi perwujudan (zuhūr) dalam berbagai manifestasi (al-mażāhir). Sedangkan menurut Shams al-Dīn Muhammad ibn Hamzah al-Fanārī (751-834), ilmu hakikat adalah ilmu tentang Allah (al-'ilm bi-Allāh) al-Haq ta'ālà, dari segi keterkaitannya

\footnotetext{
${ }^{32}$ Totok Jumantoro dan Samsul Munir Amin, Kamus Ilmu Tasawuf (Wonosobo: Penerbit Amzah, 2012), 70

33 Sayyid Muḥsin al-Mūsawī al-Tabrīz̄̄, Muntakhab Asrār al-Sharì'a (Iran: al-Ma'had al-Thaqafī Nūr 'Alà Nūr, 1423 H), 27
} 
dengan mahluk (irtabātahu bi-lkhalq), dan terpancarnya alam semesta dari-Nya, sejauh jangkauan pengetahuan manusia (bi-hasbi alțāqat al-bashariya). ${ }^{34}$

Menurut Ibrāhīm al-Kūrānī kedua pengertian tersebut pada intinya adalah sama. Keduanya menegaskan bahwa al-Haq adalah wujūd yang Absolut (muțlaq), Esa (wāhid), Niscaya (wājib) yang merupakan ungkapan dari Wujūd $($ al-wujūd $)$ dalam hubungan Pengetahuan Esensial (al-'ilmiyya al-dhātiya), yang merupakan hal yang prinsipil (al-așl) dan permulaan (mabda') dari segala entifikasi (alta'ayyunāt). ${ }^{35}$ Maka pembahasan tentang Ilmu Hakikat tidak keluar dari sudut pandang $b c$ pembahasan tentang Dia mer

\footnotetext{
${ }^{34}$ Ibrāhīm al-Kūrānī, op.cit., 182.

${ }^{35}$ Ta'ayyunāt, merupakan bentuk jamak dari kata ta'ayyun. Kata ini berarti individualisasi atau entifikasi. Istilah ini diterapkan berkenaan dengan proses penurunan Wujud Murni dalam berbagai tingkat entitas ('ayn). Misalnya, manusia adalah Wujud Absolut yang dibatasi oleh ta'ayyun (inividualisasi). Istilah ini biasanya digunakan oleh Ibn 'Arabī untuk menunjukan penentuan (partikularisasi), kekhususan, dan penamaan. Dengan demikian ta'ayyun dapat diterjemahkan sebagai peng'ayn-an, keadaan menjadi khusus, tertentukan, terspesifikasi dan terpartikularisasi, atau keadaan menjadi suatu entitas. Lihat. Seyyed Ahmad Fazeli, Mazhab Ibn Arabi Mengurai Tasybih dan Tanzih, diterjemahkan oleh Muhammad Nur Jabir (Jakarta: Sadra Press, 2016), xvii
}

pengertian ini, merupakan pembahasan tentang alam ciptaanNya (kawn) yang ditinjau dari segi keterkaitannya dengan al-Haq. ${ }^{36}$

Dengan kata lain, Ilmu Hakikat menurut Ibrāhīm al-Kūrān̄̄ adalah ilmu yang membahas wujūd al-Haq dari sudut pandang keterkaitan-Nya dengan mahluk (al-irtabațāt) bukanlah dari segi ke-Dia-an (huwa). Hal ini dikarenakan pembahasan tetang huwa tersebut, tidak akan mungkin terjangkau baik oleh simbol-simbol rasional maupun mental. Tidak ada ungkapan pantas untuk menggambarkan identitasNya, maka bagaimana mungkin untuk membahas akan hal tersebut. Adapun yang dimaksud dengan kalimat "tidak dari segi ke-Dia-an" (lā min haithu Huwa) memiliki pengertian bahwa ke-Dia-an-Nya adalah identitas yang tersembunyi (ghayb al-huwiya), yakni identitas yang tak terentifikasi (lā ta'ayyūn) karena Dia bukanlah yang terentifikasi. Tentunya tidak ada keraguan tentang sukarnya pembahasan dari sudut pandang tersebut. Hal ini karena pembahasan terdahap identitas-Nya, akan menggiring kepada kebutuhan pada bukti-bukti identifikasi atau objektifikasi sehingga dapat ditetapkannya suatu hukum atau

\footnotetext{
${ }^{36}$ Ibrāhīm al-Kūrānī, op.cit., 182
} 
definisi tentang identitas-Nya, padahal Dia adalah yang tak teridentifikasi, bahkan ketika kita mencoba untuk memberikan identifikasi bagi-Nya. ${ }^{37}$ Dengan kata lain identifikasi terhadap identitas dari al-Haq hanya sesuai dengan istilah là ta'ayyūn.

Apa yang dijelaskan oleh Ibrāhīm al-Kūrānī tersebut senada dengan yang dijelaskan oleh Ḥamzah al-Fanārī yang menjelaskan bahwa al-Haq adalah Wujūd Murni yang tidak ada pertentangan di dalam-Nya, dan Dia adalah Esa dalam ke-Esa-an yang esensial (haqīq $\bar{l}$ ), yang tidak bergatung kepada kepada segala hal yang memberi kebergantungan. ${ }^{38}$

Dikarenakan hal tersebut maka menurut al-Fanārī al-Haq adalah esensi yang Maha Suci, yang menurut teori wahdat al-wujūd, alHaq niscaya adalah Wujūd yang Esa. $^{39}$ Dengan demikian maka nyatalah bahwa berdasarkan penjelasan Ibrāhīm al-Kūrānī dan para penafsir pemikiran Ibn 'Arabī lainnya, tuduhan bahwa ajaran

${ }^{37}$ Ibrāhīm al-Kūrānī, "Ithāâf al-Dhākī Tafsir", dalam Oman Fathurahman, Ithāf al-Dhāki Tafsir Wahdatul Wujud bagi Muslim Nusantara (Jakarta: Penerbit Mizan, 2012), 182

38 Hamzah Al-Fanāry, Miṣbāh al-Uns (Iran: Intithārat Mūlā, 1384 H), 19

39 Hamzah Al-Fanāry, Mișbāḥ al-Uns (Iran: Intithārat Mūlā, 1384 H), 20 wahdat al-wujūd mengandung unsur panteisme adalah tertolak.

Dari uraian tersebut, sebagaimana yang disepakati oleh para 'ārif, Ibrāhīm al-Kūrānī juga sependapat bahwasanya pembahasan Allah berkaitan dengan ke-Dia-an atau identitas-Nya (huwizyah) tidak akan mungkin dapat dilakukan. Karenanya para sufi dalam kosmologinya mengatakan bahwa huwizyah Allah adalah takteridentifikasi ( $l \bar{a}$ ta'ayyun) yang memiliki pengertian bahwa pada tingkatan tertinggi dari huwīyah alHaq adalah suci dari segala perwujudan baik dari segi Esensi (dhāt), Atribut (sifat) atau pun Nama (asm $\bar{a}$ ). Adapun yang "tersisa" dari huwizyah al-Haq tersebut adalah Absolutisitas-Nya (al-muțlaq). Berdasarkan hal tersebut, maka pemikran para 'arif adalah sejalan dengan al-Hadits yang juga sering dijadikan dalil oleh para mutakalim dan fuqaha, yakni: tafakkarū $f i$ khalqi-Allāh wa lā tafakkarū fi-Allāh (berfikirlah tentang penciptaan Allah dan jangan janganlah berfikir tentang Allah). ${ }^{40}$

\footnotetext{
${ }^{40} \mathrm{Al}$-Hadits ini memiliki redaksi yang lain yaitu tafakkarū fi ālā'i-Allāh wa lā tafakkarū fi-Allāh, lihat di Al-Zubaydī, Takhrij al-Ahādith Ihya' 'Ulūm al-Dìn, e-book dalam http: // shamela.ws / browse.php / book-38171 / page - 2409, di akses pada tanggal 4 Januari 2016. Lihat pula dalam Hamzah Al-Fanāry, op.cit., 245,
} 
Untuk menjelaskan perbedaan Ilmu Hakikat dan Ilmu Tariqat (Suluk), Ibrāhīm al-Kūrānī mengutip pendapat Ibn 'Arabī. Bahwasanya Ilmu Hakikat adalah ilmu tetang Allah (al-'ilm bi-Allāh), sedangkan Suluk atau Ilmu Tariqat adalah ilmu tentang berbagai tingkatan-tingkatan spiritual tertinggi (al-'ilm bi-manāzil al-ākhira). Melihat perbandingan definisi kedua disiplin keilmuan tersebut, menurut Ibrāhīm al-Kūrānī, Ilmu Hakikat adalah ilmu yang memiliki tingkatan tertinggi dari berbagai ilmu-ilmu lainnya, bahkan terhadap Ilmu Tariqat. Hal tersebut dikarenakan beberapa argumentasi yakni: pertama, Ilmu Hakikat mempelajari prinsip-prinsip dasar pengetahuan yang menunjukan jalan untuk mengetahui realitas terdalam yang berkaitan dengan realitas Tuhan (al-Haq) dan alam semesta (alkhalq); kedua, Ilmu Hakikat dapat membantu untuk memahami prinsipprinsip agama yang terdapat dalam al-Quran dan al-Hadits; dan ketiga, Ilmu Hakikat adalah ilmu yang mencakup hal-hal yang sifatnya universal, hal ini karena ketika membicarakan ilmu apapun maka tidak akan terlepas dari pembicaraan tentang hakikat, terutama hakikat Tuhan. Adapun Suluk atau Ilmu
Tariqat menurut Ibrāhīm al-Kūrān̄̄ adalah pengetahuan yang berkaitan dengan peningkatan aspek batin dengan berbagai pekerjaan hati, tidak mengandung hal yang merusak, dan mengajarkan hal-hal yang menyelamatkan. Karenaya Suluk hanya bersifat praktis, hal ini berbeda dengan Ilmu Hakikat yang merupakan pengetahuan yang berbicara tentang bagaimana hubungan al-Haq dengan makhluk, dan tentang cara terpancarnya kebhinekaan dari ke-Esa-an yang hakiki, di samping tentang perbedaan antara keduanya melalui pengungkapan sifat-sifat dan tingkatannya. Maka berbeda dengan Suluk yang bersifat praktis, Ilmu Hakikat lebih bersifat teoritis. ${ }^{41}$

Penjelasan tentang keutamaan Ilmu Hakikat juga diisyaratkan oleh Ibn 'Arabī dalam al-Futūhāat alMakiyya menyatakan bahwa yang dilihat oleh Allah dari hamba-Nya bukanlah perbuatan yang ia tampakkan (zahir) dalam bentuk ibadah ritual akan tetapi apa yang tersembunyi (asrār) dibalik ritual ibadah hamba tersebut. Hal ini karena jika yang dilihat adalah perbuatan yang tampak semata, maka kesucian hati seorang 'abid hanya terkait dengan momen atau

\footnotetext{
${ }^{41}$ Ibrāhīm al-Kūrānī, op.cit., 183
}

redaksinya adalah tafakkarū fi àlā' $i$-Allāh wa lā tafakkarū fi dhāti Allāh. 
kondisi tertentu saja. ${ }^{42}$ Adapun yang dimaksud dengan asrār tersebut adalah merupakan pengetahuan yang mendalam terhadap Ilmu Hakikat, karenanya ritual ibadah yang dilakukan oleh seorang yang menjalankannya dengan tanpa didasari oleh pengetahuan yang tertanam di dalam hati sanubarinya dan hanya ikut-ikutan dengan orang lain (taqlid) sehingga tidak timbul keimanan yang mendalam di dalam dirinya terhadap agamanya, maka ia disebut sebagai muqalid. Adapun seorang muqalid tidak akan mendapatkan nikmatnya ibadah dan bahkan menganggap ibadah hanyalah sebagai beban. Demikianlah bahwasanya dengan menggabungkan Ilmu Hakikat, Tariqat dan Syari'at maka akan terciptalah kesempurnaan iman.

Menurut Ibrāhīm al-Kūrānī persyaratan utama yang harus dilakukan oleh para pencari Ilmu Hakikat adalah menegaskan bahwa tidak ada kontradiksi antara doktrin Kesatuan Wujūd ( tawhid al-wujūd) yang digagas oleh Ibn 'Arābī dengan Syari'at dan tuntutan untuk amar ma'rūf nahī munkar. Hal ini karena doktrin tawhid al-wujūd memiliki pengertian bahwa Dhät yang berhak

${ }^{42}$ Muḥy al-Dīn Ibn 'Arabī, al-Futūhāat alMakiyya, juz 3 (Beirut: Dar Sader Publishers, th), 137 . disembah dengan sebenar-benarnya oleh setiap makhluk adalah Allah yang tidak ada tuhan selain Dia, yang wujūd karena Dhat-Nya sendiri, yang menghimpun semua sifat sempurna pada diri-Nya, yang transenden dari sifat buruk dan ketidak sempurnaan, yang dengan sendiri-Nya tidak membutuhkan esensi selain Dia, yang dibutuhkan oleh setiap esensi selain-Nya yang di tangan-Nya terletak kekuasaan atas segala sesuatu, dan Dia Maha Pemelihara atas segala sesuatu. ${ }^{43}$

Ibrāhīm al-Kūrānī tidak menggunakan istilah wahdat alwujūd dalam mendefisikan pemikiran Ibn 'Arābī akan tetapi menggunakan istilah tawhid alwujūd. Penggunaan istilah tawhid alwujūd bagi pemikiran tasawuf Ibn 'Arabī mengindikasikan kehatihatian Ibrāhīm al-Kūrānī dalam membela pemikiran Ibn 'Arābī, yang oleh para penentang Ibn 'Arābī, istilah wahdat al-wujūd sering kali memiliki stigma negatif yang mengajarkan ajaran panteisme. Dalam penjelasannya tentang wahdat al-wujūd tersebut, menurut Ibrāhīm al-Kūrānī dalam menegaskan wujūd Tuhan bukan berarti harus meninggalkan Syari'at, hal ini karena menegaskan wujūd Tuhan berarti menegaskan perbedaan antara

\footnotetext{
${ }^{43}$ Ibrāhīm al-Kūrānī, op.cit, $\quad$ 203-204
} 
Tuhan sebagai wujūd Absolut (wujūd al-muțlaq) dan setiap makhluk sebagai manifestasi (tajallī) dari Nama-Nama-Nya. Dengan mengetahui perbedaan antara wujūd al-muțlaq dan tajalli-Nya maka akan timbul kesadaran bahwa manusia sebagai tajallī dari Allah adalah entitas yang lemah dan bergantung kepada Allah sebagai wujūd almuțlaq. Dengan pengetahuan ini pula penghambaan manusia kepada Allah adalah suatu keniscayaan yang harus dilakukan oleh manusia dengan cara menjalankan kewajiban Syari'at. ${ }^{44}$ Allah berfirman: "Dan semua wajah menunduk kepada Dhat yang Maha Hidup dan Maha Pemelihara" (Q.S. 20: 111).

\section{Keniscayaan} akan penghambaan mahluk kepada Tuhan dengan menjalankan kewajiban Syari'at bukanlah sebuah beban yang harus ditanggung oleh hamba melebihi kemampuan hamba itu sendiri. Ibrāhīm al-Kūrān̄̄ mengegaskan bahwa hal tersebut, dikarenakan bahwa sebagaimana yang telah dijelaskan oleh al-Quran, bahwa Allah tidak akan membebani seseorang kecuali sesuai dengan kemampuannya. $^{45}$ Dikarenakan penghambaan kepada Allah adalah sebuah keniscayaan maka dalam

\footnotetext{
${ }^{44}$ Ibid., 204
}

${ }^{45}$ Ibid., 205 menjalankan Syari'at bagi seseorang yang sudah memahami Ilmu Hakikat bukanlah sebuah beban akan tetapi sebuah kebutuhan diri untuk mencapai kesempurnaan.

Setelah keniscayaan untuk menjalankan kewajiban Syari'at telah dipahami, maka jelaslah pula hal-hal terkait dengan kewajiban Syari'at tersebut, seperti pujian (almadh), celaan (al-dhamm), pahala (al-thawāb), dan siksaan (al-'iqāb). Hal tersebut dikarenakan kesemuanya itu adalah masalah yang bersifat kontingen (mumkin, contingent) yang selalu terkait dengan Allah sebagai Wujūd yang Absolut (muthlaq al-wujūd). Adanya konsekuensi dari Syari'at di atas, maka relasi antara Tuhan dan hamba-Nya bukanlah dengan penyatuan secara absolut seperti yang terdapat dalam teori al-hulūl dan al-ittihad. Kemustahilan penyatuan secara absolut dalam kedua teori tersebut dikarenakan Allah sebagai muțlaq al-wujūd tidak sebanding dengan hamba-Nya sebagai mumkin al-wujūd. Oleh karenanya tidak akan pernah terjadi penyatuan antara keduanya. Mutlaq al-wujūd adalah wujūd yang tidak bergantung kepada apa pun, ia juga adalah wujūd yang Wujūd Niscaya (wajib al-wujūd) yang setiap sesuatu 
di alam semesta ini disandarkan kepada al-Rahman-Nya. ${ }^{46}$

Dalam menjelaskan tentang kebaikan dan keburukan atau ketaatan dan pengikaran terhadap kewajiban Syari'at, Ibrāhīm alKūrān̄̄ juga menggunakan konsep Allah sebagai muțlaq al-wujūd yang pada-Nya segala kekuasaan. Dia berkehendak untuk memberikan hidayah, juga berkehendak untuk menyesatkan mahluk-Nya. Akan tetapi Ibrāhīm al-Kūrān̄ juga menegaskan bahwa Allah adalah pemilik Nama-Nama yang baik (alasmā' al-husna) yang di dalamnya segala sifat-sifat Allah saling berpasangan. Dia Maha Memberi hidayah sekligus Maha Kuasa menyesatkan, Maha Memberi nikmat sekaligus Maha Memberi balasan, Maha Memberi manfaat sekaligus Maha Memberi petaka, Maha Menyempitkan sekaligus Maha Melapangkan dan sebagainya. ${ }^{47}$ Walaupun kedua kelompok sifat tersebut terlihat saling bertentangan, akan tetapi semuanya tetap disebut al-asmā' al-ḥusna. Dari sinilah pentingnya makna keimanan kepada kemutlakan Allah. Mengimani Absolutisitas Allah, berarti mengimani segala ketetapan Allah adalah bersifat adil. Adapun keadilan

${ }^{46}$ Ibid., 206

${ }^{47}$ Ibid., 207
Allah bukanlah merupakan tambahan bagi Absolutitisas-Nya, seperti yang diyakini oleh Mu'tazila. Orang yang memiliki persepsi tersebut maka ia tergolong orang yang akan mendapatkan kebahagiaan, dan dengan sendirinya akan selalu berpegang kepada Syari'at yang benar. Karena Syari'at dibuat tidak lain kecuali agar manusia dapat menjalani kehidupan yang benar dan penuh dengan kebahagiaan.

Al-Ghazālī mengatakan, laysa fì al-imkān abda'u min-mā kāna. Tiadalah di dalam segala hal yang mungkin itu lebih baik dari pada sesuatu yang telah ada. Ibrāhīm alKūrān̄i menjelaskan pernyataan alGhazālī tersebut bahwa segala sesuatu yang bersifat mungkin diciptakan oleh Allah adalah sempurna menurut kebutuhan yang diciptkan tersebut. Akan tetapi yang membedakan antara satu ciptaan dan ciptaan yang lain adalah tingkat kesempurnaannya, sesuai dengan ciri khas masing-masing yang berdasarkan keragaman tingkatan dan perubahan waktu. Dengan demikan, maka kelemahan atau kekurangan pada setiap mahluk adalah bagian dari kesempurnaan wujūd mahluk tersebut. Jika tidak ada kelemahan maka tidak akan ada kesempurnaan, dan karena kesempurnaan bersifat absolut maka kelemahan hanya bersifat mungkin 
dan bukanlah sebuah hal yang esensial. ${ }^{48}$ Dengan demikian maka upaya untuk menjalankan Syari'at dengan disertai pemahaman Tariqat dan Hakikat merupakan bentuk upaya untuk mencapai kesempurnaan, yakni Kesempurnaan Ilahiyah.

Berdasarkan hal tersebut, maka pada hakikatnya kesempurnaan bersifat absolut dikarenakan ia mengarah langsung kepada al-Haq. Sedangkan kelemahan hanya bersifat mungkin dan bukanlah sebuah hakikat karena ia mengarah kepada mahluk. Dengan demikian, jika kita kaitkan dengan konsep baik dan buruk, maka kebaikan adalah esensial (haqīq $\bar{l})$ sedangkan keburukan bukanlah esensial (haqī $\bar{l}$ ), atau dengan istilah lain, kebaikan adalah wujūd sedangkan keburukan adalah 'adam (ketiadaan). Adapun manusia sebagai entitas yang bersifat kontingen (mumkin), posisinya berada di dua kutub tersebut, kerenanya memiliki potensi untuk cenderung kepada salah satu dari kedua kutub tersebut. Dengan demikian kebaikan dan keburukan hanyalah bagi manusia bukan bagi Tuhan. Maka kebebasan untuk memilih di antara keduanya tersebut tidaklah berpengaruh kepada Absolutisitas Tuhan, seperti yang

${ }^{48}$ Ibid., 207 telah keliru dipahami oleh Mu'tazila yang mengatakan bahwa jika seorang hamba berbuat baik maka Tuhan "wajib" memberikan pahala kepadanya.

Kemudian Ibrāhīm al-Kūrān̄̄ menjelaskan, bahwa berdasarkan hal tersebut maka barangsiapa yang menjumpai sebuah kebaikan, hendaklah memuji Allah, karena Dia berkenan untuk mewujudkannya. Tidak ada kewajiban bagi-Nya karena pada hakikatnya Dia tidak membutuhkan alam semesta (al'ālaminn). Begitupun apabila menjumpai selain kebaikan tersebut - yakni keburukan - maka janganlah mencela kecuali kepada diri sendiri, karena sesunguhnya Allah ta'alā tidak akan mencegah sesuatu dikehendaki sesuai dengan kesanggupan (isti'dād) azalī seseorang. Allah berfirman: "...Tuhan kami ialah (Tuhan) yang telah memberikan kepada tiap-tiap sesuatu bentuk kejadiannya.." (Q.S. 20: 50). Adapun sesuatu yang telah tertampakan (al-izhār) - yang telah dilakukan oleh mahkluk - tidak akan pernah terjadi kecuali jika sesuai dengan mahluk yang menerimanya, hal tersebut karena apa yang telah diketahui oleh Allah sebelumnya, maka hal tersebut bukanlah sesuatu yang diadakan dengan tiba-tiba. Allah berfirman: "Allah mempunyai hujjah yang jelas lagi kuat; maka 
jika Dia menghendaki, pasti Dia memberi petunjuk kepada kamu semuanya" (Q.S. 6: 149). Berdasarkan hal tersebut maka tidak ada satu pun yang terjadi kecuali telah diketahui oleh Allah. Pemahaman ini menggiring kepada pengertian bahwa sifat yang saling bertentangan yang dimiliki oleh Allah, yaitu Maha Memberi petujuk dan Maha Menyesatkan (Q. S. 4: 170).

Berkaitan dengan ke-Maha Mengetahui Allah, Ibrāhīm al-Kūrānī menjelaskan firman Allah: "Wahai manusia, sesungguhnya telah datang Rasul (Muhammad) itu kepadamu dengan (membawa) kebenaran dari Tuhanmu, maka berimanlah kamu, itulah yang lebih baik bagimu. Dan jika kamu kufur, (maka kekafiran itu tidak merugikan Allah sedikitpun) karena sesungguhnya apa yang di langit dan di bumi itu adalah kepunyaan Allah. Dan adalah Allah Maha Mengetahui lagi Maha Bijaksana” (Q.S. 4: 170). Berdasarkan ayat tersebut maka keimanan dan kekufuran pada level keabsolutan al-Haq adalah sama, seperti halnya sifat-sifat-Nya yang saling bertentangan yang telah dijelaskan sebelumnya. Akan tetapi iman dan kufur tidaklah sama jika dihubungkan dengan marātib alilāhiya (levelitas Ketuhanan) yang di dalamnya terkandung perintah dan larangan, maka iman dan kufur adalah sesuatu yang berbeda. Iman adalah sesuatu yang diridhai sedangkan kufur tidak mendapat restu dari Allah. ${ }^{49}$ Allah berfirman: "Jika kamu kafir maka sesungguhnya Allah tidak memerlukanmu dan Dia tidak merestui kekufuran bagi hamba-Nya (li-'ibādihi); dan jika kamu bersyukur, niscaya Dia merestui bagimu kesyukuranmu itu" ( Q.S. 39: 7).

Adapun bentuk idāfah dari firman-Nya $l i$-'ibādihi yang bagi sebagaian kalangan meniscayakan sebuah pemahaman bahwa Allah meridhai kekufuran orang-orang yang tidak beriman, dan karena kekufuran adalah sesuatu yang direstui oleh Allah maka tiada siksaan bagi kekufuran tersebut. Ibrāhīm al-Kūrānī menjawab pernyataan tersebut dengan argumentasi bahwa peniadaan siksaan adalah jika sesuatu itu (kekufuran) bersesuaian dengan perintah Syari'at dan kebijaksanaan (Allah). Akan tetapi jika kekufuran tersebut hanya sesuai dengan kebijaksaan Allah saja, dan dilarang oleh Syari'at maka kekufuran tersebut tetap akan mengakibakan siksaan. Hal ini karena siksaan bagi kekufuran yang tidak sesuai dengan

${ }^{49}$ Ibid., 209 
aturan Syari'at adalah juga merupakan kebijaksaan Allah. ${ }^{50}$

Ibrāhīm al-Kūrānī kemudian memperjelas pernyataannya tersebut dengan mengutip pendapat Imām alJuwaynī al-Ḥaramayn (w. 1083) dalam al-Irshād, bahwa kata almahabbah (cinta) adalah berarti alirādah (kehendak) serperti halnya alriḍa (restu). Berdasarkan hal tersebut maka restu Allah terhadap kekufuran memiliki pengertian bahwa Allah merestui bahwa kekufuran tersebut dapat mengakibatkan terjadinya siksaan. Berdasarkan pernyataan ini maka hilanglah kontradiksi terhadap penafisran ayat di atas. ${ }^{51}$

Dikarenakan hal tersebut maka kewajiban Syari'at harus dilaksanakan oleh setiap manusia. Adapun pelaksanaan kewajiban Syari'at tersebut disesuaikan dengan kondisi kesiapan atau kesanggupan (isti'dad) orang yang dibebani Syari'at, apakah dalam kondisi aman atau tertekan, dalam kondisi menetap atau dalam perjalanan, merdeka atau hamba sahaya. Kewajiban Syari'at akan tetap berlaku bagi setiap manusia hingga ia meninggal dunia, hal ini sesuai dengan al-Quran, Sunnah dan Ijma'. Allah berfirman: "Dan sembahlah Tuhanmu sampai

${ }^{50}$ Ibid., 210

${ }^{51}$ Ibid., 210 datang kepadamu yang diyakini (yaqīn)..."(Q.S. 15: 99).

Ibrāhīm al-Kūrānī berpendapat bahwa kata yaqin dalam ayat di atas bermakna 'kematian'. Karenanya maksud dari ayat tersebut adalah bahwasanya manusia diperintahkan untuk menyembah Allah hingga ia meninggal dunia. Ibrāhīm al-Kūrān̄̄ menentang dengan keras sufi yang menafsirkan kata yaqin dengan alkashf, sehingga mengakibatkan pemahaman bahwa sufi yang telah mencapai kashf telah gugur segala kewajiban Syari'atnya. Pemahaman ini tentu bertentangan dengan Syari'at yang memerintahkan untuk menyembah Allah kapan pun dan di mana pun manusia berada hingga ajal menjemputnya. Begitupun pemaham ini bertentangan dengan akal, yang mana penghambaan kepada Allah bagi seorang manusia tidak akan pernah selesai, dan bentuk dari penghambaan tersebut salama manusia masih berada di alam dunia adalah dalam bentuk pengamalan Syari'at. Adapun jika argumentasi yang digunakan adalah bahwa kashf adalah tersingkapnya sesuatu dari alam yang tersembunyi atau alam almalakūt, sehingga menjadikan landasan argumentasi bahwa kashf merupakan puncak dari ibadah sehingga setelah kashf kewajiban ibadah atau menjalankan Syari'at bagi seseorang hilang, maka hal itu 
pun tertolak. Ibrāhīm al-Kūrān̄̄ menjelaskan bahwa pada malam isra', Nabi Muhammad melihat Allah, dengan demikian pada saat itu berarti Nabi Muhammad telah mengalami kashf. Akan tetapi menurut Ibrāhīm al-Kūrānī, kewajiban-kewajiban Syari'at yang ada sekarang ini, seperti zakat, puasa, haji dsb., diperintahkan setelah peristiwa kashf yang dialami oleh Nabi Muhammad tersebut. ${ }^{52}$ Dengan demikian kashf tidak dapat dijadikan landasan untuk menggugurkan kewajiban Syari'at bahkan pada kenyataannya kashf merupakan awal dari diwajibkannya kewajiban Syari'at bagi umat Islam.

Penafsiran yang keliru bahwa kashf dapat dijadikan justifikasi untuk meninggalkan Syari'at mengindikasikan bahwa setiap Muslim dalam beribadah haruslah dilandasi dengan dasar-dasar keilmuan yang benar terutama terhadap al-Quran dan al-Hadits. Hal tersebut penting untuk dilakukan agar tidak dapat dengan mudah bersikap taqlid terhadap pernyataanpernyataan yang bertentangan dengan Syaria't. Berkaitan dengan pengamalan Syari'at, Ibn 'Arabī menyatakan bahwa setiap pengamalan Syari'at haruslah dilandasi dengan ilmu bukan

${ }^{52}$ Ibid., 211 berdasarkan taqlid. Adapun alasan bahwa pengamalan Syari'at harus dilakukan bagi orang yang berilmu ('âlim) adalah dikarenakan dua alasan, yaitu: pertama, seorang 'alim yang salih adalah seorang yang memiliki perhatian yang cermat, misalnya dalam memahami firman Allah: "Dan bagi kalian, bahwa di dalam qisas terdapat kehidupan" yang memiliki makna tersembunyi yaitu menyelamatkan hak-hak setiap orang beriman; kedua, menetapkan keadilan penghambaan (al'ubudiyahi), dan menampakan kemuliaan Ketuhanan (alrubūbiyah). ${ }^{53}$ Dengan memahami dua aspek tersebut maka pengamalan Syari'at atau ibadah akan dilakukan dengan penuh kesadaran dan tanpa adanya paksaan dari pihak mana pun.

Berkaitan

pentingnya menjalankan Syari'at, Ibrāhīm alKūrān̄̄ mengutip perkataan Ibn 'Arabī, yang menyatakan bahwa delapan anggota tubuh manusia, yakni: mata, telinga, lidah, tangan, perut, alat kelamin, kaki dan hati memiliki kewajiban Syari'atnya masing-masing yang harus dipenuhi. Menurut Ibn 'Arabī semua amal perbuatan yang dilakukan oleh setiap

\footnotetext{
${ }^{53}$ Muhyi al-Dīn Ibn 'Arabī, "Al-Tanzilāt alMawșuliya fì Asrār al-Ṭāhirāt wa-l-Ṣalawāt wa1-Ayām al-Aṣliya", dalam Majmū'ah Rasāil Ibn 'Arabī Jilid 2. (Beirut: Dār al-Maḥajah alBayḍā, 2000), 155
} 
anggota tubuh tersebut, adalah fondasi kehendak dan jalan sufi, yang tidak dapat digugurkan hingga ia meninggal dunia. Jika seorang sālik yang mempelajari Ilmu Hakikat malalaikan fondasi-fondasi tersebut dalam tindakan dan perilakunya, maka niscaya ia telah terpedaya lagi tersesat. Hal ini karena bagi seorang yang telah wușūl (menguasai Ilmu Hakikat), tidak akan terpikirkan sama sekali untuk meninggalkan semua fondasi tersebut. Jika orang yang mengaku telah wuṣūl akan tetapi meninggalkan Syari'at maka ia adalah pendusta. Bahkan seandainya pengetahuan tentang dua dunia dan rahasia terbuka baginya, itu hanyalah tipuan dan muslihat semata. Jadi, dengan demikian tidak ada kemungkinan untuk wuṣūl hingga puncak yang bersih dari kotoran kejahatan, dan bebas dari tujuan yang mementingkan diri sendiri, selama orang yang hendak menempuh jalan ini tidak menghilangkan dahulu liarnya nafsur dan keruhnya naluri kemanusiaan (al-bashariya). ${ }^{54}$

Berdasarkan uraian tersebut maka menurut Ibrāhīm al-Kūrānī antara Ilmu Hakikat, Ilmu Tariqat, dan Ilmu Syari'at bukanlah sesuatu yang bertentangan satu sama lain. Ketiga ilmu tersebut saling melengkapi menjadi satu kesatuan yang utuh dalam menjalankan agama Islam. Ilmu Hakikat adalah ilmu yang bersifat universal dibandingkan Ilmu Tariqat. Sedangkan Ilmu Tariqat lebih luas dari Ilmu Syari'at. Maka apabila digambarkan maka cakupan ketiga ilmu tersebut seperti piramida terbalik.

\section{F. Penutup}

Ibrāhīm al-Kūrānī merupakan tokoh terpenting dalam perkembangan Islam di Indonesia. Pemikiran-pemikiran Ibrāhīm alKūrānī merupakan embrio atau cikal bakal dari corak Islam yang ada di Nusantara. Pengakuan terhadap peran Ibrāhīm al-Kūrān̄ dalam perkembangan Islam di Nusantara, juga dilakukan oleh Pengurus Pusat Lembaga Takmir Masjid Nahdlatul Ulama yang secara resmi telah menyatakan bahwa Ibrāhīm alKūrānī merupakan salah satu mata rantai (sanad) Nahdlatul Ulama dalam fiqih Mazhab Syafi'i.

\section{Daftar Pustaka}

Al-Kūrānī, Ibrāhīm, Itḥăf al-Dhakī, dalam Oman Fathurahman, Ithāf al-Dhakī Tafsir Wahdatul Wujud bagi Muslim Nusantara (Jakarta: Penerbit Mizan, 2012).

${ }^{54}$ Ibrāhīm al-Kūrānī, op.cit., 213 
Azra, Azyumardi, Jaringan Ulama Timur Tengah dan Kepulauan Nusantara Abad XVII dan XVIII Akar Pembaruan Islam Indonesia (Jakarta: Kencana Prenadamedia Group, 2013), 91.

Bruinessen, Martin Van, "Mencari Ilmu dan Pahala di Tanah Suci Orang Nusantara Naik Haji” dalam Ulumul Qur'an Jurnal Ilmu dan Kebudayaan No. 5 (Jakarta: Lembaga Studi Agama dan Filsafat, 1989).

Bruinessen, Martin Van, "Studies of Sufism and the Sufi Orders in Indonesia Source", dalam Die Welt des Islams (Brill: Vol. 38, Issue 2, Jul., 1998).

Fathurahman, Oman, "Tarekat Syattāriyah Memperkuat Ajaran Neosufisme," dalam Mengenal dan Memahami Tarekat-Tarekat Muktabarah di Indonesia (Jakarta: Kencana, 2011) .

Fathurahman, Oman, Ithāf al-Dhaki Tafsir Wahdatul Wujud bagi Muslim Nusantara (Jakarta: Penerbit Mizan, 2012).

Knysh, Alexander, "Ibrāhīm al-Kūrānī (d. 1101/1690), an Apologist for Wạ̣dat al-Wujūd", dalam Journal of The Royal Asiatic Society (Cambrige: Cambrige
Univesity Press, Vol. 5. No. 1. Apr., 1995).

Nafi, Basheer M., "Tașawwuf and Reform in Pre-Modern Islamic Culture: In Search of Ibrāhīm alKūrānī," dalam Die Welt des Islams, (Brill: Vol. 42. Issue 3, 2002).

Jumantoro, Totok dan Samsul Munir Amin, Kamus Ilmu Tasawuf (Wonosobo: Penerbit Amzah, 2012).

Al-Tabrīzī, Sayyid Muhsin al-Mūsawī, Muntakhab Asrār al-Sharī'a (Iran: al-Ma'had al-Thaqafĩ Nūr 'Alà Nūr, 1423 H).

Fazeli, Seyyed Ahmad, Mazhab Ibn Arabi Mengurai Tasybih dan Tanzih, diterjemahkan oleh Muhammad Nur Jabir (Jakarta: Sadra Press, 2016) .

Al-Fanāry, Ḥamzah, Miṣbāh al-Uns (Iran: Intithārat Mūlā, 1384 H) .

Ibn 'Arabī, Muḥy al-Dīn, al-Futūhāat alMakiyya, juz 3 (Beirut: Dar Sader Publishers, tth) .

Ibn 'Arabī, Muḥy al-Dīn, “Al-Tanzilāt al-Mawșuliya fī Asrār al-Ṭāhirāt wa-l-Șalawāt wa-l-Ayām alAṣliya”, dalam Majmū'ah Rasāil Ibn 'Arabī Jilid 2. (Beirut: Dār al-Maḥajah alBayḍā, 2000). 